\title{
A thymidine kinase-negative bovine herpesvirus 5 is highly attenuated for rabbits, but is neuroinvasive and establishes latent infection ${ }^{1}$
}

\author{
Sara Campos da Silva², Mário Celso Speroto Brum³ ${ }^{3}$, Stephan A.M. de \\ Oliveira $^{2}$, Rudi Weiblen ${ }^{4}$ and Eduardo F. Flores ${ }^{4 *}$
}

\begin{abstract}
Silva S.C., Brum M.C.S., Oliveira S.A.M., Weiblen R. \& Flores E.F. 2011. A thymidine kinase-negative bovine herpesvirus 5 is highly attenuated for rabbits, but is neuroinvasive and establishes latent infection. Pesquisa Veterinária Brasileira 31(5):389397. Departamento de Medicina Veterinária Preventiva, Universidade Federal de Santa Maria, Camobi, Santa Maria, RS 97105-900, Brazil. E-mail: eduardofurtadoflores@ gmail.com

Mutant viral strains deleted in non-essential genes represent useful tools to study the function of specific gene products in the biology of the virus. We herein describe an investigation on the phenotype of a bovine herpesvirus 5 (BoHV-5) recombinant deleted in the gene encoding the enzyme thymidine kinase (TK) in rabbits, with special emphasis to neuroinvasiveness and the ability to establish and reactivate latent infection. Rabbits inoculated with the parental virus (SV-507/99) $(n=18)$ at a low titer $\left(10^{5.5} \mathrm{TCID}_{50}\right)$ shed virus in nasal secretions in titers up to $10^{4.5} \mathrm{TCID}_{50}$ for up to 12 days (average: 9.8 days [5-12]) and $5 /$ 16 developed neurological disease and were euthanized in extremis. Rabbits inoculated with the recombinant BoHV-5TK $\Delta$ at a high dose $\left(10^{7.1} \mathrm{TCID}_{50}\right)$ also shed virus in nasal secretions, yet to lower titers (maximum: $10^{2.3} \mathrm{TCID}_{50}$ ) and for a shorter period (average: 6.6 days [2-11]) and remained healthy. PCR examination of brain sections of inoculated rabbits at day 6 post-infection (pi) revealed a widespread distribution of the parental virus, whereas DNA of the recombinant BoHV-5TK $\Delta$-was detected only in the trigeminal ganglia [TG] and olfactory bulbs [OB]. Nevertheless, during latent infection (52pi), DNA of the recombinant virus was detected in the TGs, OBs and also in other areas of the brain, demonstrating the ability of the virus to invade the brain. Dexamethasone (Dx) administration at day 65 pi was followed by virus reactivation and shedding by $5 / 8$ rabbits inoculated with the parental strain (mean duration of 4.2 days [1 -9]) and by none of seven rabbits inoculated with the recombinant virus. Again, PCR examination at day 30 post-Dx treatment revealed the presence of latent DNA in the TGs, OBs and in other areas of the brain of both groups. Taken together, these results confirm that the recombinant BoHV-5TK $\Delta$ is highly attenuated for rabbits. It shows a reduced ability to replicate in the nose but retains the ability to invade the brain and to establish latent infection. Additional studies are underway to determine the biological and molecular mechanisms underlying the inability of BoHV-5TK $\Delta$ to reactivate from latency.
\end{abstract}

INDEX TERMS: BoHV-5, mutant phenotype, attenuation, neuroinvasiveness, neurovirulence.

\footnotetext{
1 Received on November 12, 2010.

Accepted for publication on December 6, 2010.

2 Programa de Pós-Graduação em Medicina Veterinária (PPGMV), Universidade Federal de Santa Maria (UFSM), Santa Maria, RS 97105-900, Brazil.

${ }^{3}$ Faculdade de Veterinária, Universidade do Pampa (Unipampa), BR 472 Km 585, Uruguaiana, RS 97500-970, Brazil.

${ }^{4}$ Setor de Virologia, Departamento de Medicina Veterinária Preventiva (DMVP), Centro de Ciências Rurais (CCR), Universidade Federal de Santa Maria (UFSM), Camobi, Santa Maria, RS, 97105-900, Brazil. ${ }^{*}$ Corresponding author eduardofurtadoflores@gmail.com
}

RESUMO.- [Cepa do herpesvírus bovino tipo 5 defectiva na timidina quinase é altamente atenuada para coeIhos mas é neuroinvasiva e estabelece infecção latente.] Cepas virais mutantes defectivas em genes não essenciais se constituem em ferramentas úteis para o estudo da função de proteínas virais na biologia dos vírus. Este estudo relata uma investigação do fenótipo, em coelhos, de uma cepa recombinante do herpesvírus bovino tipo 5 (BoHV-5) defectiva na enzima timidina quinase (TK), com ênfase para a neuroinvasividade e capacidade de estabelecer e reativar 
a infecção latente. Coelhos inoculados com o vírus parental (SV-507/99, $n=18$ ) em baixo título $\left(10^{5,5} \mathrm{TCID}_{50}\right)$ excretaram o vírus nas secreções nasais em títulos de até $10^{4,5} \mathrm{TCID}_{50} /$ $\mathrm{mL}$ por até 12 dias (média: 9,8 dias [5-12]) e 5/16 desenvolveram doença neurológica e morreram ou foram eutanasiados in extremis. Em contraste, coelhos inoculados com o recombinante BoHV-5TK $\Delta$ em alto título $\left(10^{7,1} \mathrm{TCID}_{50}\right)$ excretaram o vírus em títulos inferiores (máximo $10^{2,3} \mathrm{TCID}_{50}$ / $\mathrm{mL}$ ), por um período menor (média: 6,6 days [2-11]) e permaneceram saudáveis. A realização de PCR em seções do encéfalo no dia 6 pós-infecção (pi) revelou uma ampla distribuição do DNA do vírus parental, enquanto o DNA do vírus recombinante foi detectado apenas nos gânglios trigêmeos [TGs] e nos bulbos olfatórios [OBs]. Não obstante, durante a infecção latente (52pi), o DNA do vírus recombinante foi detectado nos TGs, OBs e em outros locais do encéfalo, demonstrando que o vírus recombinante mantém a neuroinvasividade. Tratamento com dexamethasona (Dx) no dia 65 pi resultou em reativação e excreção viral por $5 / 8$ dos coeIhos inoculados com o vírus parental (duração média de 4,2 dias [1-9]) e por nenhum dos sete coelhos inoculados com o vírus recombinante. No entanto, PCR realizado no dia 30 pós-Dx revelou a presença de DNA latente do BoHV-5TK $\Delta$ nos TGs, OBs e em outras áreas do encéfalo. Esses resultados confirmam que o recombinante BoHV-5TK $\Delta$ é altamente atenuado para coelhos. A sua capacidade de replicação na mucosa nasal é reduzida, mas mantém a capacidade de invadir o encéfalo e estabelecer infecção latente. Estudos adicionais estão em andamento para elucidar os mecanismos responsáveis pela incapacidade do recombinante de reativar a infecção latente.

TERMOS DE INDEXAÇÃO: BoHV-5, fenótipo mutante, neurovirulência, neuroinvasividade.

\section{INTRODUCTION}

Bovine herpesvirus type 5 (BoHV-5) is an enveloped DNA virus that belongs to the family Herpesviridae, subfamily Alphaherpesvirinae, genus Varicellovirus (Roizman et al. 1992). BoHV-5 infection has been associated with meningoencephalitis in cattle, a disease frequently described in South American countries, especially Brazil and Argentina, where numerous outbreaks are reported every year (Carrillo et al. 1983, Salvador et al. 1998, Rissi et al. 2008, Silva et al. 2007).

Like other alphaherpesviruses, e.g. human herpes simplex type 1 (HSV-1) and pseudorabies virus (PRV), BoHV-5 is neuroinvasive and neurovirulent in their natural hosts and in animal models ( Lee et al. 1999, Vogel et al. 2003). After primary replication in the nasal epithelia, BoHV-5 disseminates into the central nervous system (CNS) through axonal transport, using the olfactory and/or trigeminal pathway (Chowdhury et al. 1997, Lee et al. 1999, Diel et al. 2005). In the first, the virus invades dendrites of olfactory receptor neurons located in the olfactory epithelium and is transported to the main olfactory bulbs through axonal transport. In the second pathway, the virus invades the maxillary nerve endings and reaches the trigeminal ganglia (TG), whose neurons projects to neurons in the pons and medulla oblongata (Chowdhury et al. 1997, Lee et al. 1999). Neurological signs in BoHV-5 inoculated rabbits are predominantly associated with viral dissemination and neuronal lesions after invasion by the olfactory pathway ( Lee et al. 1999, Diel et al. 2005).

Several gene products are involved in viral replication and dissemination of alphaherperviruses in the central nervous system (CNS) (Enquist et al. 1998). The thymidine kinase (TK) enzyme - encoded by all known herpesviruses is involved in the metabolism of deoxyribonucleotides, an activity necessary for virus replication in non-dividing cells, such as neurons (Smith et al. 1991, Tikoo et al. 1995). The TK gene is classified as non-essential since its deletion does not impair the ability of the virus to replicate in cell culture (Brum et al. 2010). Nonetheless, TK is required for the full expression of herpesvirus neurovirulence in vivo (Enquist et al. 1998). Deletion of TK gene in HSV-1 and PRV has been associated with deficient replication in neurons and reduced neurovirulence (Chen et al. 2004, Ferrari et al. 2000). The ability to establish latent infection does not seem to be affected in TK-negative viruses, like HSV-1, PRV and bovine herpesvirus type 1 (BoHV-1) (Chen et al. 2004, Ferrari et al. 2000, Whetstone et al. 1992). However, the ability to reactivate the infection is usually severely impaired, if not abolished, depending on the viruses, animal and experimental procedures (Coen et al. 1989, Mengeling 1991, Whetstone et al. 1992, Ferrari et al. 2000).

Since BoHV-5 displays a marked neurotropism and its replication in the brain results in severe neurological signs and neuropathology, it is reasonable to assume that TK plays an important role in BoHV-5 neuropathogenesis. In a previous studies, a Brazilian BoHV-5 TK negative strain (BoHV-5TK $\Delta$ ) was shown to be attenuated in a rabbit model (Silva et al. 2010) and a BoHV-5 brivudin-resistant strain probably defective in TK activity- was also attenuated in rabbits (Brum et al. 2009). However, in none of these studies the ability of the virus to spread into the CNS following IN inoculation was addressed.

In the present article, we investigated the pathogenesis of acute and latent infection by a BoHV-5TK $\Delta$ strain in a rabbit model. The results presented herein confirm and extend previous observations (Silva et al. 2010) which indicate that the recombinant is fully attenuated for rabbits after IN inoculation. Interestingly, the recombinant retains the ability to invade and to replicate to a certain extent in the CNS during acute infection, albeit without producing neurological disease. Even though the ability of establish latent infection remains present, the mutant does not reactivate upon dexamethasone administration (Dx).

\section{MATERIALS AND METHODS}

\section{Experimental design}

Groups of weanling rabbits were inoculated intranasally (IN) with the parental virus (SV507/99, $\mathrm{n}=18$ ) or with the recombinant BoHV-5TK $\Delta(n=14)$ and submitted to clinical, virological and serological monitoring during acute infection. 
At day 65 post-inoculation (pi), inoculated animals of both groups were submitted to dexamethasone (Dx) administration and monitored thereafter. To address viral neuroinvasiveness, rabbits inoculated with the recombinant and with the parental virus were euthanized at day 6 pi and at day 5 after Dx administration $(\mathrm{pDx})$. To detect latent viral DNA, rabbits were euthanized for detection of viral DNA by PCR in brain sections at days 52 pi and 30 pDx.

\section{Viruses and cells}

The Brazilian BoHV-5 strain SV507/99 - isolated from a cow with neurological disease in southern Brazil and submitted to sequencing of the entire genome (Delhon et al. 2003) - was used as the parental virus to construct the recombinant lacking the TK gene, BoHV-5TK $\Delta$ (Brum et al. 2010). All procedures of virus multiplication, isolation and serological tests were performed in a MDBK-derived cell line named CRIB (ATCC-CRL 11883). In vitro growth kinetics was performed in rabbit kidney cells (RK-13; ATCC-CCL 37). Cells were maintained in MEM (minimum essential medium, Invitrogen, Brazil), supplemented with $10 \%$ fetal bovine serum (Cultilab, Brazil), $100 \mathrm{U} / \mathrm{mL}$ of penicillin and $100 \mu \mathrm{g} / \mathrm{mL}$ of streptomycin (Nutricell, Brazil).

\section{In vitro growth kinetics}

Prior to rabbit inoculation, the ability of the parental virus and the recombinant BoHV-5TK $\Delta$ to replicate in RK-13 cells was assayed in an one step growth curve according to Brum et al. (2010). RK-13 cell monolayers were inoculated either the recombinant or the parental strain at a multiplicity of infection of 5 . At intervals after virus inoculation (0, 4, 10, 18 and 24 hours) aliquots of culture supernatants were harvested and submitted to virus quantitation by limiting dilution. Virus titers were calculated according to Reed \& Muench (1938) and expressed as $\log _{10}$ median tissue culture infectious dose per mililiter $\left(\mathrm{TCID}_{50} / \mathrm{mL}\right)$.

\section{Animals, virus inoculation and dexamethasone (Dx) administration}

Thirty-two about 30 day-old weanling New Zealand rabbits were allocated into two groups and maintained in separated cages without contact with each other. One group was inoculated with BoHV-5TK $\Delta$ in a dose of $10^{7.1} \operatorname{TCID}_{50}(n=14)$ and the other group $(n=16)$ was inoculated with the parental virus $\left(10^{5.5} \operatorname{TCID}_{50}\right)$. To study neuroinvasiveness, three animals were also inoculated with the parental virus at a high dose $\left(10^{7.5} \mathrm{TCID}_{50}\right)$, a titer that produces neurological infection and disease in virtually $100 \%$ of the rabbits (Caron et al. 2002. The animals were inoculated IN with $1 \mathrm{~mL}$ of a viral suspension into the paranasal sinuses $(0.5 \mathrm{~mL}$ in each side) through nephrine openings (Silva et al. 1999) after tranquilization with tiletamine/zolazepan $(30 \mathrm{mg} / \mathrm{kg}$ IM; Zoletil, Virbac, Brazil). At day $6 \mathrm{pi}, 2$ rabbits of the parental virus group and 3 of the recombinant virus group were euthanized for examining brain sections for viral DNA by PCR. Beginning at day 65 pi Day 0pDx), the remaining rabbits were submitted to five daily administrations of dexamethasone (Dx, $2.6 \mathrm{mg} / \mathrm{kg} /$ day, Decadronal, Achè, Brazil) by the intramuscular route. Rabbits of the BoHV-5TK $\Delta$ group were euthanized at days 5 post-Dx (pDx) or at day $30 \mathrm{pDx}$ to search for viral DNA in brain tissues.

\section{Monitoring, sample collection and processing}

Rabbits were monitored twice a day for clinical signs during the entire experimental period. Nasal swabs for virus isolation were collected daily up to day $12 \mathrm{pi}$ and $12 \mathrm{pDx}$. Viral isolation was performed in CRIB cells according to standard protocols (Diel et al. 2007). Quantitation of virus in nasal swabs was performed by submitting pools of nasal secretions (each pool contained nasal secretions collected from 4 animals) to limiting dilution. Sera obtained from blood samples collected at days 0 , $52 \mathrm{pi}, 65 \mathrm{pi}(0 \mathrm{pDx})$ and $30 \mathrm{pDx}$ were submitted to a standard virus neutralizing assay (VN) for neutralizing antibodies (Diel et al. 2007). Geometric mean titers (G) of neutralizing antibodies of each group were calculated according $G=2^{(\log x 1+\log \times 2+\ldots \log x n) / n}$ (Toma et al. 1999). Swabs that were positive for virus were subsequently submitted to virus quantitation by limiting dilution.

To address viral neuroinvasiveness, at day 6 pi (acute infection) three rabbits inoculated with the recombinant and two inoculated with a high dose of SV507/99 strain (10 $\left.7.5 \mathrm{TCID}_{50}\right)$ were euthanized to collect neural tissues: olfactory bulb $(\mathrm{OB})$; anterior ( $\mathrm{AC}$ ) and ventro-lateral cortex (VLC); trigeminal ganglia (TG), pons/medulla oblongata (PO/MO), thalamus (Th) and cerebellum (CB) (Mayer et al. 2006). These sections were maintained at $-80^{\circ} \mathrm{C}$ until DNA extraction was performed. At day $5 \mathrm{pDx}$ (after Dx treatment) three other rabbits of each group infected with BoHV-5TK $\Delta$ and SV507/99 strain (dose $10^{5.5}$ $\mathrm{TCID}_{50}$ ) were euthanized. At day $52 \mathrm{pi}$ and $30 \mathrm{pDx}$, animals of both groups were also euthanized and the neural tissues were collected to confirm latent infection.

All procedures of animal handling and experimentation were performed according to recommendations by the Brazilian Committee on Animal Experimentation (COBEA; law \#6.638 of 8th May 1979). The animal experiments were approved by an Institutional Ethics and Animal Welfare Committee (Comitê de Ética e Bem Estar Animal, Universidade Federal de Santa Maria, UFSM, approval \#44/2008; process \#23081.010078/2008-41).

\section{DNA extraction and PCR}

Neural tissues collected at day 6 pi (acute infection), at day 5 pDx (after Dx administration), 52 pi and 30 pDx (latent infection) were submitted to total DNA extraction using phenol-chloroform protocol (Vogel et al. 2003). Total DNA was submitted to a nested PCR using two set of primers corresponding to positions 57.338 and 57.782 (primers 1 and 2) and 57.372 and 57.666 (primers 3 and 4 ) of the glycoprotein $\mathrm{B}(\mathrm{gB})$ gene coding region of the BoHV5 strain SV507/99, essentially as described by Diel et al. (2007). Total DNA extracted from the brain of a control non-infected rabbit, and from a rabbit with acute BoHV-5 infection was used as negative and positive controls, respectively. PCR products were analysed under UV light after electrophoresis in a 1.5\% agarose gel stained with ethidium bromide.

\section{RESULTS}

\section{One step growth curve}

As the recombinants were amplified and characterized in bovine cells (CRIB), before inoculation in rabbits we investigated its ability to replicate in cultured rabbit cells. The one step growth curve experiment performed in RK-13 cells demonstrated that the recombinant BoHV-5TK $\Delta$ replicated with similar kinetics and to a similar titer to those of the parental virus(Fig.1). In a previous experiment in CRIB cells, this recombinant was also shown to replicate to equivalent titers to that of the parental virus (Brum et al. 2010). Thus, a possible impairment in replicating in rabbits 


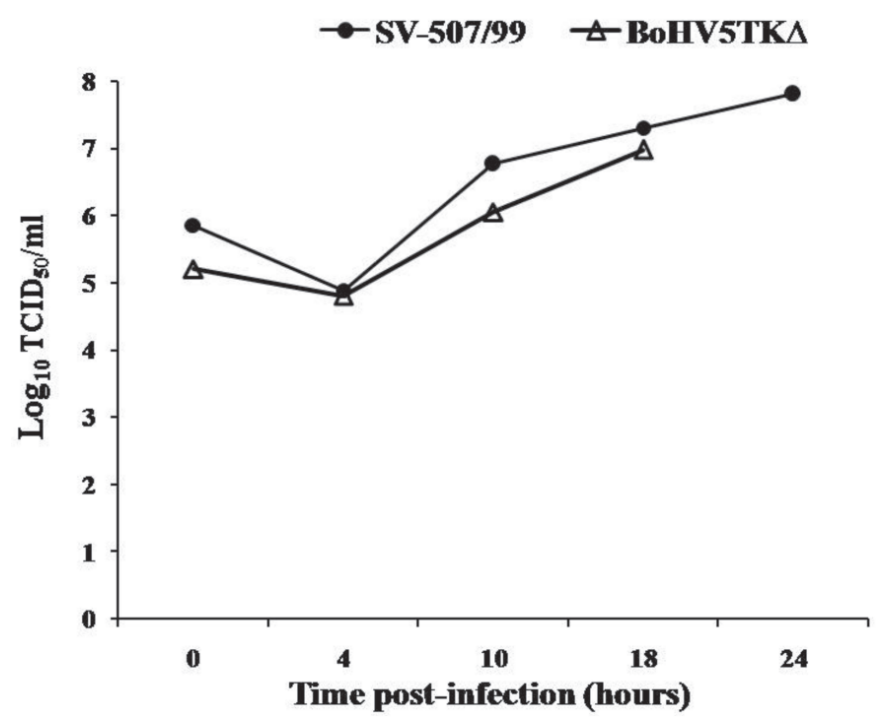

in vivo would not be attributable to a gross defect of replication in rabbit cells.

\section{Acute infection}

The main clinical, virological and serological findings observed during acute infection are presented in Table 1. All rabbits inoculated with SV507/99 (dose of $10^{5.5} \mathrm{TCID}_{50}$ ) shed virus in nasal secretions up to day $12 \mathrm{pi}$, with a mean period of excretion of 9.8 days (5-12). Despite of the low viral dose inoculated, five out of sixteen rabbits (the other two were euthanized at day $6 \mathrm{pi}$ ) developed severe neurological signs between days 10 and 13 pi (rabbits \#18,

Fig.1. One step growth curve of replication of BoHV-5 SV-507/ 99 and recombinant BoHV-5TK $\Delta$ in rabbit kidney cells (RK13). Cells were inoculated with a m.o.i of 5 and aliquots of culture supernatants were collected at different intervals and submitted to virus quantitation by limiting dilution.

Table 1. Virological, serological and clinical findings after inoculation of rabbits with BoHV-5 SV-507/99 or with the recombinant BoHV-5TK $\Delta$

\begin{tabular}{|c|c|c|c|c|c|c|c|c|c|c|c|c|c|c|}
\hline \multirow[t]{2}{*}{ Virus } & \multicolumn{12}{|c|}{ Virus shedding (dpi) } & \multirow{2}{*}{$\begin{array}{c}\text { VN } \\
\text { (day 33) }\end{array}$} & \multirow[t]{2}{*}{ History } \\
\hline & 1 & 2 & 3 & 4 & 5 & 6 & 7 & 8 & 9 & 10 & 11 & 12 & & \\
\hline \multicolumn{15}{|c|}{ BoHV-5TK $\Delta$} \\
\hline 1 & + & + & + & + & + & $+^{a}$ & & & & & & & NT & Euthanasia (6dpi)a \\
\hline 2 & + & + & + & + & + & $-a$ & & & & & & & NT & Euthanasia (6dpi)a \\
\hline 3 & - & - & + & - & + & $+^{a}$ & & & & & & & NT & Euthanasia (6dpi)a \\
\hline 4 & + & + & - & - & - & - & - & - & - & - & - & - & 2 & $\mathrm{n} / \mathrm{a}$ \\
\hline 5 & + & + & + & + & + & + & + & - & - & - & - & - & 8 & $\mathrm{n} / \mathrm{a}$ \\
\hline 6 & + & + & + & + & + & + & + & + & - & - & - & - & 16 & $\mathrm{n} / \mathrm{a}$ \\
\hline 7 & - & + & + & - & - & + & - & - & - & - & - & - & 2 & $\mathrm{n} / \mathrm{a}$ \\
\hline 8 & + & - & + & - & - & + & + & + & + & - & - & - & 2 & $\mathrm{n} / \mathrm{a}$ \\
\hline 9 & + & + & + & + & + & + & + & + & - & - & - & - & 8 & $\mathrm{n} / \mathrm{a}$ \\
\hline 10 & + & + & + & + & + & - & - & - & - & - & - & - & 4 & $\mathrm{n} / \mathrm{a}$ \\
\hline 11 & - & + & + & + & + & + & + & + & + & - & - & + & 4 & $\mathrm{n} / \mathrm{a}$ \\
\hline 12 & + & - & + & + & + & + & - & - & - & - & - & - & 4 & $\mathrm{n} / \mathrm{a}$ \\
\hline 13 & - & - & - & - & - & - & - & - & - & - & - & - & 8 & $\mathrm{n} / \mathrm{a}$ \\
\hline 14 & + & - & - & + & + & + & + & - & - & - & - & - & 16 & $\mathrm{n} / \mathrm{a}$ \\
\hline \multicolumn{15}{|c|}{ SV507/99 } \\
\hline 15 & - & + & + & + & + & + & + & + & - & + & - & - & 4 & $\mathrm{n} / \mathrm{a}$ \\
\hline 16 & + & + & + & + & + & + & + & + & + & + & - & + & 4 & $\mathrm{n} / \mathrm{a}$ \\
\hline 17 & + & + & + & + & + & + & + & + & + & + & + & + & 4 & $\mathrm{n} / \mathrm{a}$ \\
\hline 18 & + & + & + & + & + & + & + & + & + & + & & & NT & $\begin{array}{l}\text { Seizures (euthanasia } \\
\text { day 10pi) }\end{array}$ \\
\hline 19 & + & + & + & + & + & + & + & + & + & + & + & + & 8 & $\mathrm{n} / \mathrm{a}$ \\
\hline 20 & - & + & + & + & + & $+^{\mathrm{a}}$ & & & & & & & NT & Euthanasia (6dpi)a \\
\hline 21 & + & + & + & + & + & $+^{\mathrm{a}}$ & & & & & & & NT & Euthanasia (6dpi) ${ }^{a}$ \\
\hline 22 & - & + & + & + & + & + & + & - & + & - & - & - & $\mathrm{NT}$ & $\begin{array}{l}\text { Blindness, bruxism, } \\
\text { opisthotonus (eutaná- } \\
\text { sia day 13pi) }\end{array}$ \\
\hline 23 & - & + & + & + & + & + & + & + & + & + & + & - & 2 & $\mathrm{n} / \mathrm{a}$ \\
\hline 24 & + & + & + & + & + & + & + & + & + & - & - & - & NT & $\begin{array}{l}\text { Bruxism, depression } \\
\text { (euthanasia day 13pi) }\end{array}$ \\
\hline 25 & - & + & + & + & + & + & + & + & + & $+^{b}$ & & & $\mathrm{NT}$ & $\begin{array}{l}\text { Bruxism, opísthotonus } \\
\text { (euthanasia day 11pi) }\end{array}$ \\
\hline 26 & + & + & + & + & + & + & + & - & - & + & - & - & 4 & $\mathrm{n} / \mathrm{a}$ \\
\hline 27 & - & - & + & + & + & + & + & + & + & + & - & + & 2 & $\mathrm{n} / \mathrm{a}$ \\
\hline 28 & - & - & - & - & + & + & + & + & + & - & - & - & 4 & $\mathrm{n} / \mathrm{a}$ \\
\hline 29 & - & + & + & + & + & + & + & + & + & + & - & - & $<2$ & $\mathrm{n} / \mathrm{a}$ \\
\hline 30 & - & + & + & + & + & + & + & + & + & - & - & + & $\mathrm{NT}$ & $\begin{array}{l}\text { Bruxism, seizures (eu- } \\
\text { thanasia day 13pi) }\end{array}$ \\
\hline 31 & - & + & + & + & + & + & + & + & + & + & + & - & 4 & $\mathrm{n} / \mathrm{a}$ \\
\hline 32 & - & + & + & + & + & + & + & + & + & + & + & - & 4 & $\mathrm{n} / \mathrm{a}$ \\
\hline
\end{tabular}

$\bar{a}$ Euthanasia for collection of brain sections for PCR; ${ }^{b}$ Death after neurological signs. 


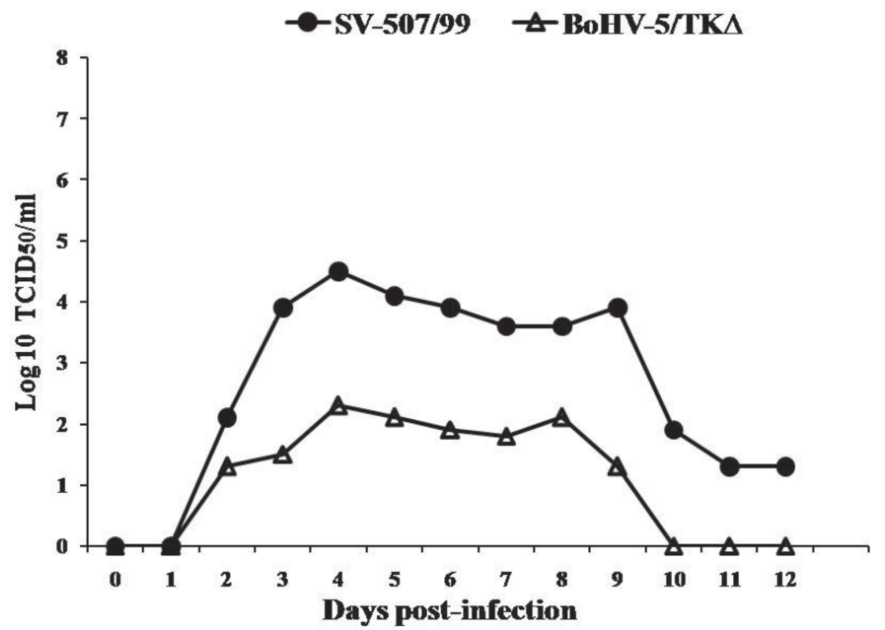

Fig.2. Mean virus titers in nasal secretions of rabbits inoculated with the parental virus BoHV-5 SV-507/99 or with the recombinant BoHV-5TK $\Delta$.

22, 24, 25 and 30). The signs were depression or excitation, ptialism, bruxism, opisthotonus and seizures. These animals were euthanized in extremis and infectious virus was isolated from several areas of their brain (data not shown).

Most rabbits (13/14) inoculated with the recombinant BoHV-5TK $\Delta$ (dose of $10^{7.1} \mathrm{TCID}_{50}$ ) shed virus in nasal secretion up day 9 pi (2-9), however for a shorter period (mean 6.6 days). Virus shedding was intermittent in some animals. None of the animals inoculated with the recombinant virus developed neurological disease. One animal of this group was found death in the cage at day $12 \mathrm{pi}$, however no infectious virus was recovered from the brain.

The mean titers of virus shedding in both groups are presented in Figure 2. In general, rabbits inoculated with the recombinant virus shed virus in titers approximately $2 \log _{10}$ lower than the animals inoculated with the parental virus (Fig.2).

Most rabbits inoculated with the parental and recombinant strains developed neutralizing antibodies at day $33 \mathrm{pi}$ (Table 1). The geometric mean titer (GMT) of the group $\mathrm{BoHV}-5 \mathrm{TK} \Delta$ (2.36) was higher than the GMT of the parental group (1.90). This difference may be explained by the high dose used to inoculate the rabbits with the recombinant virus (100 times higher than the parental strain). Seroconversion could not be assessed in several animals euthanized during acute infection (Table 1).

Taken together, the results of virus isolation and serology demonstrate that the recombinant virus retained the ability to replicate in the nasal mucosa of rabbits. The extent and duration of virus shedding, however, were significantly reduced comparing to the parental strain.

\section{Latent infection}

No infectious virus was detected in nasal swabs collected at day 52 pi from rabbits inoculated with both strains. The absence of virus replication characterized latent infection. PCR examination of brain sections of three rabbits inoculated with the recombinant virus revealed the presence of viral DNA in the TGs, OBs and in other sections of the trigeminal (rabbits \# 4 and 5) and olfactory pathways (rabbit \# 6) (Table 3). No infectious virus was detected in these sections upon inoculation of tissue homogenates into CRIB cells. These results indicated that animals were latently infected before Dx administration.

\section{Reactivation of latent infection}

Following Dx administration - starting at day $65 \mathrm{pi}$, five out of eight rabbits inoculated with parental strain shed virus

Table 2. Virological and serological findings after dexamethasone (Dx) treatment of rabbits with BoHV-5 SV-507/99 or with the recombinant BoHV-5TKA

\begin{tabular}{|c|c|c|c|c|c|c|c|c|c|c|c|c|c|}
\hline \multirow[t]{2}{*}{ Virus } & \multicolumn{10}{|c|}{$\begin{array}{l}\text { Vírus shedding } \\
\text { (day pi) }\end{array}$} & \multicolumn{2}{|c|}{$\begin{array}{l}\text { VN antibodies } \\
\text { (day pDx) }\end{array}$} & \multirow[t]{2}{*}{ History } \\
\hline & $1-3$ & 4 & 5 & 6 & 7 & 8 & 9 & 10 & 11 & 12 & 0 & 30 & \\
\hline \multicolumn{14}{|c|}{ BoHV-5TK $\Delta$} \\
\hline \multicolumn{14}{|c|}{ Rabbit \# } \\
\hline 7 & - & - & - & - & - & - & - & - & - & - & 32 & 8 & $\mathrm{n} / \mathrm{a}$ \\
\hline 8 & - & - & - & - & - & - & - & - & - & - & $<2$ & nt & Death $(13 d D x)$ \\
\hline 10 & - & - & - & - & - & - & - & - & - & - & $<2$ & $<2$ & $\mathrm{n} / \mathrm{a}$ \\
\hline 11 & - & - & - & - & - & - & - & - & - & - & $<2$ & $<2$ & $\mathrm{n} / \mathrm{a}$ \\
\hline 12 & - & - & - & - & - & - & - & - & - & - & 4 & 2 & $\mathrm{n} / \mathrm{a}$ \\
\hline 13 & - & - & - & - & - & - & - & - & - & - & 16 & 2 & $\mathrm{n} / \mathrm{a}$ \\
\hline 14 & - & - & - & - & - & - & - & - & - & - & 32 & 4 & $\mathrm{n} / \mathrm{a}$ \\
\hline \multicolumn{14}{|c|}{ SV507/99 } \\
\hline \multicolumn{14}{|c|}{ Rabbit \# } \\
\hline 15 & - & - & + & - & - & + & + & - & - & - & 4 & 4 & $\mathrm{n} / \mathrm{a}$ \\
\hline 16 & - & + & - & + & + & + & + & + & + & + & 4 & 32 & $\mathrm{n} / \mathrm{a}$ \\
\hline 17 & - & - & - & - & - & - & - & - & - & - & 4 & 4 & $\mathrm{n} / \mathrm{a}$ \\
\hline 19 & - & - & - & - & - & - & - & $-a$ & $\mathrm{nt}$ & nt & 8 & nt & Death $(11 \mathrm{dDx})$ \\
\hline 23 & - & - & - & - & - & - & + & - & - & - & 2 & 2 & $\mathrm{n} / \mathrm{a}$ \\
\hline 27 & - & - & + & + & + & - & + & - & - & - & 2 & 4 & $\mathrm{n} / \mathrm{a}$ \\
\hline 29 & - & - & - & - & + & - & - & - & - & - & $<2$ & $<2$ & $\mathrm{n} / \mathrm{a}$ \\
\hline 32 & - & - & - & - & - & - & - & - & - & - & 4 & $\mathrm{nt}$ & Death $(15 \mathrm{dDx})$ \\
\hline
\end{tabular}

a Found dead in the cage at day $11 \mathrm{pDx}$. 
Table 3. Distribution of viral DNA in brain sections of rabbits inoculated with BoHV-5 SV-507/99 or with the recombinant BoHV-5TK $\Delta$, at different time-points after infection

\begin{tabular}{|c|c|c|c|c|c|c|c|c|c|}
\hline & \multirow{2}{*}{$\begin{array}{l}\text { BoHV-5 strain } \\
\left(T_{C I D}\right)\end{array}$} & \multirow{2}{*}{$\begin{array}{c}\text { Animal } \\
(\#)\end{array}$} & \multicolumn{6}{|c|}{ Brain sections ${ }^{\mathrm{a}}$} & \multirow[t]{2}{*}{ Observations } \\
\hline & & & OB & VLC & $\mathrm{AC}$ & Th/CB & $\mathrm{PO} / \mathrm{MO}$ & $\mathrm{TG}$ & \\
\hline \multirow{5}{*}{$\begin{array}{l}\text { Acute infection } \\
\text { day } 6 \mathrm{pi}\end{array}$} & SV507/99 & 20 & - & - & - & + & + & + & \multirow{5}{*}{$\begin{array}{l}\text { SV } 507 / 99 \text { - invasion of } 2^{\text {nd }} \\
\text { and } 3^{\text {rd }} \text { order neurons of the } \\
\text { TG and OB pathways; } \\
\text { BoHV-5TK } \Delta \text { - infection of } \\
\text { entry sites of the brain. }\end{array}$} \\
\hline & $\left(10^{7.5}\right)$ & 21 & + & + & + & - & + & - & \\
\hline & BoHV-5TK $\Delta$ & 1 & + & - & - & - & - & + & \\
\hline & $\left(10^{7.1}\right)$ & 2 & + & - & - & - & - & + & \\
\hline & & 3 & + & - & - & - & - & + & \\
\hline \multirow{3}{*}{$\begin{array}{l}\text { Latent infection } \\
\quad \text { day } 52 \mathrm{pi}\end{array}$} & BoHV-5TK $\Delta$ & 4 & + & - & - & + & + & + & \multirow{3}{*}{$\begin{array}{l}\text { Reached } 2^{\text {nd }} \text { and } 3^{\text {rd }} \text { order } \\
\text { neurons of the two pathways. }\end{array}$} \\
\hline & $\left(10^{7.1}\right)$ & 5 & + & - & - & - & + & + & \\
\hline & & 6 & - & + & + & - & + & + & \\
\hline \multirow{6}{*}{$\begin{array}{c}\text { After } D x \\
\text { administration } \\
\text { day } 5 p\end{array}$} & SV507/99 & 26 & - & + & - & + & + & + & \multirow{3}{*}{$\begin{array}{l}\text { Reached } 2^{\text {nd }} \text { and } 3^{\text {rd }} \text { order } \\
\text { neurons of both pathways }\end{array}$} \\
\hline & $\left(10^{5.5}\right)$ & 28 & - & - & - & - & - & + & \\
\hline & & 31 & + & + & + & + & + & + & \\
\hline & BoHV-5TK $\Delta$ & 11 & - & - & - & - & - & - & \multirow{3}{*}{$\begin{array}{l}\text { Reached } 2^{\text {nd }} \text { and } 3^{\text {rd }} \text { order } \\
\text { neurons of both pathways }\end{array}$} \\
\hline & $\left(10^{7.1}\right)$ & 12 & + & - & - & + & + & + & \\
\hline & & 14 & + & + & - & + & + & + & \\
\hline \multirow{3}{*}{$\begin{array}{l}\text { Latent infection } \\
\text { day } 30 \mathrm{pDx}\end{array}$} & BoHV-5TK $\Delta$ & 7 & - & - & - & - & - & + & \multirow{3}{*}{$\begin{array}{l}\text { Reached } 2^{\text {nd }} \text { and } 3^{\text {rd }} \text { order } \\
\text { neurons of both pathways }\end{array}$} \\
\hline & $\left(10^{7.1}\right)$ & 10 & + & - & - & + & - & - & \\
\hline & & 13 & - & + & - & + & + & - & \\
\hline
\end{tabular}

a $\mathrm{OB}=$ olfactory bulb; VLC = ventro-lateral cortex (amygdala); $\mathrm{AC}=$ anterior cortex; $\mathrm{Th}$ = thalamus; $\mathrm{CB}=$ cerebellum; $\mathrm{PO}=$ pons; $\mathrm{MO}=$ medulla oblongata; $\mathrm{TG}=$ trigeminal ganglia .

in nasal secretions (mean duration $=4.25$ days [1-9] $)$ (Table 2). No neurological signs were recorded in these animals and only one presented an increase in VN titer after Dx administration (rabbit \# 16). In rabbits inoculated with BoHV5TK $\Delta$, no viral shedding, clinical disease or increase in VN titers were observed (Table 2). Two rabbits inoculated with the parental strain (rabbits \# 19 and 32) and one inoculated with BoHV-5TK $\Delta$ (\# 18) died between day 11 and 15 pDx, yet no infectious virus was recovered from their brains. Probably, these deaths were due to the high dose of Dx used in the attempt to reactivate the infection.

Taken together, these results indicate that the absence of TK did not prevent the establishment of latent infection by the recombinant $\mathrm{BoHV}-5 \mathrm{TK} \Delta$ but did impair reactivation and shedding upon corticosteroid treatment.

\section{Spread of BoHV-5TK $\Delta$ within the CNS}

To address the ability of the recombinant virus to invade the CNS (neuroinvasiveness) from the site of inoculation, rabbits were euthanized at day 6 pi (acute infection). Virus shedding was detected in nasal swabs of rabbits of both groups prior to euthanasia, confirming that the virus was replicating in the nasal mucosa. Investigation of viral DNA in neural tissues at that day demonstrated the presence of BoHV-5TK $\Delta$ only in TGs and OBs (Table 3). In contrast, the parental strain was widely distributed in the brain of two rabbits (\# 20 and 21) euthanized at this day, reaching VLC and AC (rabbit \# 21) and PO/MO and TAL/CB (rabbit \# 20) (Table 3). These sites correspond to second and third-order neurons of the olfactory and trigeminal pathways, respectively. Infectivity was demonstrated in a few brain sections of rabbits inoculated with the parental virus, but not in rabbits inoculated with the recombinant (not shown). These data demonstrated that the parental strain reached deep areas of the brain at day 6 pi whereas the recombinant reached only the initial areas of the CNS through the olfactory and trigeminal pathways. Taken alone, these data would indicate a defect (or a delay) of the recombinant to invade the brain after reaching the TGs and OBs during early acute infection.

We further investigated the ability of the recombinant to invade the brain by testing brain sections by PCR at days 52 pi (latency), 5 pDx (after Dx treatment) and $30 \mathrm{pDx}$ (latency). Rabbits inoculated with the parental strain were euthanized at day $5 \mathrm{pDx}$. Examination of the brain of rabbits inoculated with the recombinant at day 52 pi revealed BoHV5TK $\triangle$ DNA in TGs, OBs and in additional areas of the brain, noticeably TAL/CB and PO/MO (rabbits \# 4 and 5) and VLC and AC (rabbit \# 6) (Table 3). Thus, contrasting with the lack of detection of viral DNA in deep areas of the brain at day $6 \mathrm{pi}$, these data indicate that the recombinant was indeed capable of spreading into the CNS during acute infection, reaching second and third-order neurons of the olfactory and trigeminal pathways. The lack of detection of viral DNA beyond the TGs and OBs at day 6pi, therefore, might reflect a delay in the invasion and/or replication of the recombinant in nervous tissue.

At day $5 \mathrm{pDx}$, the recombinant virus showed a wide distribution (DNA or infectious virus) in the brain of two rabbits (\# 12 and 14), similar to that observed at day 52 pi, reaching the PO/MO and Th/CB (\# 12) and PO/MO, Th/CB and VLC (\# 14) (Table 3). This distribution was similar to that of the parental strain (Table 3). At day 30pDx, recombinant virus DNA was also detected in second and third-order neurons of both olfactory and trigeminal pathways, demonstrating the ability of this virus to invade the brain. The lack of detection of infectious virus in these areas confirmed the status of latent infection.

Taken together, the results of mapping viral DNA by 
PCR in the brain of inoculated rabbits at late times after infection (latent infection) indicate that the recombinant BoHV-5TK $\Delta$ was able to invade the brain and to establish latent infection in several neural areas. The levels of virus replication and dissemination within the brain, however, were probably too low to produce neuropathology and clinical signs. This would explain the absence of neurological disease in rabbits inoculated with the recombinant virus. Thus, the recombinant BoHV-5TK $\Delta$ is fully attenuated for rabbits, albeit retaining the ability to replicate in the nasal mucosa, to invade the brain and to establish latent infection.

\section{DISCUSSION}

We herein investigated the ability of the recombinant BoHV5TK $\Delta$ to invade and to disseminate within the brain of rabbits after intranasal inoculation. This recombinant was constructed out of a neurovirulent Brazilian BoHV-5 strain (Brum et al. 2010) and was previously shown to be attenuated for rabbits (Silva et al. 2010) and calves (Santos et al. 2010). In the present study we demonstrated that the recombinant - in spite of being completely avirulent for rabbits retains the ability to replicate in the nose to moderate titers and is capable to invade and replicate to certain levels in the brain. Moreover, we confirmed that BoHV-5TK $\Delta$ does establish latent infection in sites of the brain, but is not reactivated upon Dx administration.

The enzyme thymidine kinase (TK) of alphaherpesviruses is a product of an early gene required for viral DNA replication in neurons, but is not essential for viral replication in epithelial cells or in cell cultures (Chen et al. 1998, 2004, Enquist et al. 1998). Even though TK is non-essential for viral replication in dividing cells, alphaherpesviruses defective in TK activity usually show a reduced ability to replicate in peripheral tissues compared to their TK+ counterparts (Kaashoek et al. 1996, Ferrari et al. 2000). Herein, we demonstrated that BoHV-5TK $\Delta$ replicates with reduced efficiency in the nasal mucosa of rabbits. Even inoculated with a 100-fold higher dose, the titers in nasal secretions were $2 \log _{10}$ lower than the parental strain (Fig.2). The duration of virus shedding was also reduced. The reduced ability to replicate in the nose of rabbits would not be attributed to a gross defect of replication in rabbit cells, since the virus yield in RK-13 cells was similar to that of the parental virus (Fig. 1). Interestingly, the mean VN titer (GMT) of the recombinant virus group was higher than the parental virus group, probably reflecting the high amount of input virus (Table 1). Thus, deletion of TK from the BoHV-5 genome resulted in a reduced ability of the recombinant virus to replicate in the nose of rabbits. Similar findings were observed in pigs inoculated with TK-deleted strains of PRV, which retained the ability of replicate in the site of inoculation, yet to a lesser extent than the parental virus (Ferrari et al. 1998, 2000). Similarly, an HSV-1 TK negative strain was able to replicate in the cornea of rats in lower levels than the wild type virus (Chen et al. 2004). In recent experiment the recombinant BoHV-5TK $\Delta$ was shown to replicate less efficiently (both in titer and duration) than the parental virus in the na- sal mucosa of experimentally infected calves (Santos et al. 2010) and rabbits (Silva et al. 2010).

Rabbits inoculated with BoHV-5TK $\Delta$ did not develop neurological disease and viral DNA was not detected by PCR in their brains during acute infection (day 6 pi). In contrast, DNA of the parental virus was detected in several areas of the CNS at day 6 , indicating an efficient neuroinvasion after nasal replication. Similar findings were reported for an attenuated PRV TK-deleted strain, whose viral replication in the brain of pigs was severely impaired at day 3 and 8 pi compared with parental strain (Ferrari et al. 2000). The migration of the virus to the CNS (olfactory and trigeminal nervous pathways) was reduced comparing to the parental strain (Ferrari et al. 2000). Likewise, viral replication in trigeminal ganglia of rats infected with HSV-1TK-negative was largely impaired at day 1 pi (Chen et al. 2004).

In contrast with early infection (day 6 pi), BoHV-5TK $\Delta$ DNA was detected in several areas of the brain at late times (day $52 \mathrm{pi}, 5$ and $30 \mathrm{pDx}$ ) (Table 3). The distribution of recombinant virus DNA was somehow similar to that of the parental virus (in spite of the $2 \log _{10}$ difference in input virus). Moreover, $31 \%$ of rabbits inoculated with the parental virus developed neurological disease during acute infection, infectious virus was found widely distributed in the brains (data not show). Similar finding were reported following infection of pigs with a PRV TK-deleted strain, where viral DNA was detected - although in lower amounts than parental virus DNA - in several areas of the brain, including third and fourth order neurons of olfactory and trigeminal pathways (Ferrari et al. 2000). In both studies - BoHV-5 and PRV TK deleted - inoculated animals did not develop neurological disease, probably reflecting the low level of invasion and replication in the brain. Thus, although our PCR results indicate that BoHV-5TK $\Delta$ can reach and replicate in deep areas of the brain, we suggest that the level of virus replication is too low to produce massive neuronal infection, damage and neuropathology.

Detection of BoHV-5TK $\triangle$ DNA in brain tissues indicates that some level of virus replication did occur in these areas, similarly to that described for a PRV TK-deleted strain in pigs (Ferrari et al. 2000). It is unlikely that the DNA detected in the brain was derived from viral particles passively transported to these sites through axonal flow. As TK activity is essential for efficient replication of other alphaherpesviruses in non-dividing, neuronal cells (Ferrari et al. 2000), it would be interesting to investigate whether BoHV5 is less dependent on its own TK activity to replicate in neurons. It cannot be discarded that viral spread in the CNS in the absence of viral encoded TK might be related to the ability of the virus to take advantage of cellular enzymes involved in the synthesis of deoxyribonucleotides for DNA repair (Chen et al. 1998). A previous study with HSV-1 strains expressing different cellular enzymes involved in nucleoside phosphorylation demonstrated that a human cellular TK can replace viral TK, allowing viral replication and reactivation from latency in trigeminal ganglia (Chen et al. 1998). Another hypothesis is that deoxythymi- 
dine monophosphate, also known as thymidylate, may arise from cellular sources like mitochondrial TK or residual cytosolic TK and then lead to formation of deoxythymidine triphosphate by cellular thymidylate kinases (Chen et al. 1998). Regardless the mechanism, the data presented herein suggest that low levels of BoHV-5TK $\Delta$ replication in neural tissues may occur in the absence of viral TK.

The consistent detection of viral DNA in the TGs and OBs of rabbits inoculated with the recombinant (Table 3 ) indicates an efficient establishment of latent infection. Similar results were demonstrated for the recombinant BoHV5TK $\Delta$ in rabbits, in which reactivation was not detected (Silva et al. 2010) and in calves, where reactivation was only barely detected (Santos et al. 2010). Indeed, several studies on other TK-negative alphaherpesviruses have demonstrated that lack of viral TK activity would not prevent the establishment of latency, even by viruses with reduced ability to replicate at the inoculation sites (Coen et al. 1989, Mengeling 1991, Whetstone et al. 1992, Ferrari et al. 1998, 2000, Chen et al. 2004). Thymidine kinase-defective HSV1 mutants are severely impaired for replication in trigeminal ganglia of mice, but are still able to establish latency (Chen et al. 2004). The ability of TK-negative viruses to reactivate latent infection, however, is usually severely impaired and even completely abolished in some systems (Coen et al. 1989, Jacobson et al. 1993, Tenser et al. 1996, Chen et al. 2004). Thus, our results corroborate previous observations in other TK-defective alphaherpesviruses in which latent infection is established but not reactivated. The reasons for the inability of most TK-negative alphaherpesviruses to reactivate after an efficient establishment of latency are not understood (Coen et al. 1989, Tenser et al. 1996, Ferrari et al. 1998, 2000, Chen et al. 2004).

In summary, the results presented herein demonstrate that the recombinant BoHV-5TK $\Delta$ strain is able to replicate in nasal mucosa - yet less efficiently than the parental virus -, can invade and spread within the brain at certain levels, without producing neurological sings. Moreover, the recombinant is able to establish latent infection but is not reactivated upon corticosteroid treatment. The biological and molecular basis underlying the inability of this recombinant to reactivate from latency are currently under investigation.

\section{REFERENCES}

Brum M.C.S., Santos C.M.B., Weiblen R. \& Flores E.F. 2009. Selection and characterization of brivudin resistant bovine herpesvirus type 5 . Braz. J. Microbiol. 40:1132-1140.

Brum M.C., Weiblen R., Flores E.F. \& Chowdhury S.I. 2010. Construction and growth properties of bovine herpesvirus type 5 recombinants defective in the glycoprotein $\mathrm{E}$ or thymidine kinase gene or both. Braz. J. Med. Biol. Res. 43:217-224.

Caron L., Flores E.F., Weiblen R., Scherer C.F.C., Irigoyen L.F., Roehe P.M., Odeon A. \& Sur J-H. 2002. Latent infection by bovine herpesvirus type -5 in experimentally infected rabbits: Virus reactivation, shedding and recrudescence of neurological disease. Vet. Microbiol. 84(4):285-295

Carrillo B.J., Ambrogi A., Schudel A.A., Vazquez M., Dahme E. \&
Pospischil A. 1983. Meningoencephalitis caused by IBR virus in calves in Argentina. Zentralbl. Veterinärmed. B 30:327-332.

Chen S.H., Cook W.J., Grove K.L. \& Coen D.M. 1998. Human thymidine kinase can functionally replace herpes simplex virus type 1 thymidine kinase for viral replication in mouse sensory ganglia and reactivation from latency upon explant. J. Virol. 72:6710-6715.

Chen S.H., Pearson A. \& Coen D.M. 2004. Failure of thymidine kinasenegative herpes simplex virus to reactivate from latency following efficient establishment. J. Virol. 78:520-523.

Chowdhury S.I., Lee B.J., Mosier D., Sur J.H., Osorio F.A., Kennedy G. \& Weiss M.L. 1997. Neuropathology of bovine herpesvirus type 5 (BHV-5) meningo-encephalitis in a rabbit seizure model. J. Comp. Pathol. 117:295-310.

Coen D.M., Kosz-Vnenchak M., Jacobson J.G., Leib D.A., Bogard C.L., Schaffer P.A., Tyler K.L. \& Knipe D.M. 1989. Thymidine kinasenegative herpes simplex virus mutants establish latency in mouse trigeminal ganglia but do not reactivate. Proc. Natl Acad. Sci. U.S.A. 86:4736-4740.

Delhon G., Moraes M.P., Lu Z., Afonso C.L., Flores E.F., Weiblen R., Kutish G.F. \& Rock D.L. 2003. Genome of bovine herpesvirus 5. J. Virol. 77:10339-10347.

Diel D.G., Almeida S.R., Brum M.C., Dezengrini R., Weiblen R. \& Flores E.F. 2007. Acute and latent infection by bovine herpesvirus type 5 in experimentally infected goats. Vet. Microbiol. 121:257-267.

Diel D.G., Fonseca E.T., Souza S.F., Mazzanti A., Bauermann F., Weiblen R. \& Flores E.F. 2005. O herpesvírus bovino tipo 5 (BoHV5) pode utilizar as rotas olfatória ou trigeminal para invadir o sistema nervoso central de coelhos, dependendo da via de inoculação. Pesq. Vet. Bras. 25:164-170.

Enquist L.W., Husak P.J., Banfield B.W. \& Smith G.A. 1998. Infection and spread of alphaherpesviruses in the nervous system. Adv. Virus Res. 51:237-347.

Ferrari M., Gualandi G.L., Corradi A., Monaci C., Romanelli M.G., Tosi G. \& Cantoni A.M. 1998. Experimental infection of pigs with a thymidine kinase negative strain of pseudorabies virus. Comp. Immunol Microbiol. Infect. Dis. 21:291-303.

Ferrari M., Mettenleiter T.C., Romanelli M.G., Cabassi E., Corradi A., Dal Mas N. \& Silini R. 2000. A comparative study of pseudorabies virus (PRV) strains with defects in thymidine kinase and glycoprotein genes. J. Comp. Pathol. 123:152-163.

Kaashoek M.J., Van Engelenburg F.A., Moerman A., Gielkens A.L., Rijsewijk F.A. \& Van Oirschot J.T. 1996. Virulence and immunogenicity in calves of thymidine kinase- and glycoprotein E-negative bovine herpesvirus 1 mutants. Vet. Microbiol. 48:143-53.

Lee B.J., Weiss M.L., Mosier D. \& Chowdhury S.I. 1999. Spread of bovine herpesvirus type 5 (BHV-5) in the rabbit brain after intranasal inoculation. J. Neurovirol. 5:474-484.

Mayer S.V., Quadros V.L., Vogel F.S., Winkelmann E.R., Arenhart S., Weiblen R. \& Flores E.F. 2006. Dexamethasone-induced reactivation of bovine herpesvirus type 5 latent infection in experimentally infected rabbits results in a broader distribution of latent viral DNA in the brain. Braz. J. Med. Biol. Res. 39:335-343.

Mengeling W.L. 1991. Virus reactivation in pigs latently infected with a thymidine kinase negative vaccine strain of pseudorabies virus. Arch. Virol. 120:57-70.

Reed L.J. \& Muench H. 1938. A simple method for estimating fifty per cent end points. Am. J. Hyg. 27:493-497.

Rissi D.R., Pierezan F., Silva M.S., Flores E.F. \& Barros C.S. 2008. Neurological disease in cattle in southern Brazil associated with bovine herpesvirus infection. J. Vet. Diagn. Invest. 20:346-349.

Roizman B., Desrosiers R.C., Fleckenstein B., Lopez C., Minson A.C. \& Studdert M.J. 1992. The family Herpesviridae: An update. Arch. Virol. 123:432-445.

Salvador S.C., Lemos R.A.A., Riet-Correa F., Roehe P.M. \& Osório A.L.A.R. 
1998. Meningoencefalite em bovinos causada por herpesvírus bovino5 no Mato Grosso do Sul e São Paulo. Pesq. Vet. Bras. 18:76-83.

Santos C.M.B., Anzilliero D., Bauermann F.V., Brum M.C.S., Weiblen R. \& Flores E.F. 2011. Experimental infection of calves with recombinants of bovine herpesvirus 5 defective in glycoprotein $E(\mathrm{gE})$, thymidine kinase (TK) and both gE/TK. Pesq. Vet. Bras. 31(4):319-325.

Silva A.M., Flores E.F., Weiblen R., Canto M.C., Irigoyen L.F., Roehe P.M. \& Sousa R.S. 1999. Pathogenesis of meningoencephalitis in rabbits by bovine herpesvirus type-5 (BHV-5). Rev. Microbiol. 30:22-31.

Silva M.S., Brum M.C.S., Weiblen R. \& Flores E.F. 2007. Identificação e diferenciação de herpesvírus bovino tipos 1 e 5 isolados de amostras clínicas no Centro-Sul do Brasil, Argentina e Uruguai (19872006). Pesq. Vet. Bras. 27:403-408.

Silva S.C., Brum M.C., Weiblen R., Flores E.F. \& Chowdhury S.I. 2010. A bovine herpesvirus 5 recombinant defective in the thymidine kinase (TK) gene and a double mutant lacking TK and the glycoprotein E gene are fully attenuated for rabbits. Braz. J. Med. Biol. Res. 43:150-159.

Smith G.A., Young P.L. \& Mattick J.S. 1991. Nucleotide and amino acid sequence analysis of the thymidine kinase gene of a bovine encephalitis herpesvirus. Arch. Virol. 119:199-210.

Tenser R.B., Gaydos A. \& HAY K.A. 1996. Reactivation of thymidine kinase-defective herpes simplex virus is enhanced by nucleoside. J. Virol. 70:1271-1276.

Tikoo S.K., Campos M. \& Babiuk L.A. 1995. Bovine herpesvirus 1 (BHV-1): Biology, pathogenesis, and control. Adv. Virus Res. 45:191223.

Toma B., Vaillancout J.P., Dufour B., Eloit M.G., Marsh W., Bénet J.J., Sanaa M. \& Michel P. 1999. Dictionary of Veterinary Epidemiology. lowa State Universtiy Press, Ames.

Vogel F.S., Caron L., Flores E.F., Weiblen R., Winkelmann E.R., Mayer S.V. \& Bastos R.G. 2003. Distribution of bovine herpesvirus type 5 DNA in the central nervous systems of latently, experimentally infected calves. J. Clin. Microbiol. 41:4512-4520.

Whetstone C.A., Miller J.M., Seal B.S., Bello L.J. \& Lawrence W.C. 1992. Latency and reactivation of a thymidine kinase-negative bovine herpesvirus 1 deletion mutant. Arch. Virol. 122:207-214. 